\title{
Complete sequence and organization of the Serratia marcescens biotin operon
}

\author{
Naoki Sakurai, $†$ Hiroyuki Akatsuka, Eri Kawai, Yuji Imai and \\ Saburo Komatsubara†
}

Author for correspondence: Naoki Sakurai. Tel: +8148433 2737. Fax: +81484332734.

e-mail : nsakurai@tanabe.co.jp

Research Laboratory of Applied Biochemistry, Tanabe Seiyaku Co. Ltd, 16-89 Kashima-3-chome, Yodogawa-ku, Osaka 532, Japan

\begin{abstract}
The nucleotide sequence of the biotin (bio) operon of wild-type Serratia marcescens Sr41 was determined. Five ORFs were identified to encode BioA (7,8-diaminopelargonic acid aminotransferase), BioB (biotin synthase), Biof (7-keto-8-aminopelargonic acid synthase), BioC (an enzyme catalysing the synthesis of pimeloyl-COA) and BioD (dethiobiotin synthase), in this order. The operon was deduced to be transcribed divergently to the left into bioA and to the right into the bioBFCD genes. The promoters and a common predicted operator for both bioA and bioBFCD genes were located between the biOA and bioB genes. The predicted amino acid sequences of these enzymes were similar to the sequences of the corresponding enzymes of Escherichia coli. Analysis of expression of the lacz structural gene fused with the bioA and bioB promoters revealed that the biotin operon was subject to biotin-mediated feedback repression.
\end{abstract}

Keywords: biotin biosynthesis, biotin operon, Serratia marcescens

\section{INTRODUCTION}

In micro-organisms, D-biotin is synthesized from pimeloyl-CoA through four enzymic steps (Fig. 1) (Eisenberg, 1987; Bachmann, 1990). The precursors of pimeloyl-CoA are still unknown although some micro-organisms have been reported to convert pimelic acid to pimeloyl-CoA (Izumi et al., 1974; Ploux et al., 1992; Sanyal et al., 1994b; Ifuku et al., 1994). In Escherichia coli, the biosynthetic pathway from pimeloyl-CoA to D-biotin includes 7-keto8-aminopelargonic acid (KAPA), 7,8-diaminopelargonic acid (DAPA) and dethiobiotin, and the five biotin biosynthetic enzymes are encoded by the bio $A B F C D$ genes, which together form an operon, the biotin (bio) operon (Fig. 1) (Eisenberg, 1987; Bachmann, 1990). In addition, the bioH gene, unlinked to this bio cluster, is involved in an unknown and early step before pimeloylCoA synthesis. The final step in D-biotin biosynthesis remains un-elucidated because of the unusual nature of

†Present address: Lead Generation Research Laboratory at Toda, Tanabe Seiyaku Co. Ltd, 2-50, Kawagishi-2-chome, Toda-shi, Saitama 335, Japan.

Abbreviations: DAPA, 7,8-diaminopelargonic acid; KAPA, 7-keto-8aminopelargonic acid.

The GenBank/EMBLDDBJ accession number for the sequence reported in this paper is $D 17468$. the transformation reaction and an unknown source of the sulfur atom (Demoll \& Shieve, 1983; Parry, 1983; Ifuku et al., 1992).

In E. coli, transcription of the bio operon is repressed by biotin, which is converted by the $\operatorname{bir} A$ product into a corepressor, biotinyl 5'-adenylate (Barker \& Campbell, 1981; Prakash \& Eisenberg, 1979). The bio $A$ gene is transcribed leftward and the bioBFCD genes are transcribed rightward by the action of the promoters located between the bio $A$ and bio $B$ genes and controlled by a common operator (Guha, 1971).

Serratia marcescens is an enteric bacterium. Classical mutagenesis and molecular genetic techniques have been employed to construct various L-amino acid-hyperproducing strains of this bacterium, which have been used commercially for $\mathrm{L}$-amino acid production (Komatsubara, 1994). Recently, D-biotin-producing strains of $S$. marcescens Sr41 have been constructed by selection of mutants resistant to acidomycin, a biotin analogue (Sakurai et al., 1993a). Among these strains, SB304 and SB412 produced D-biotin at 5 and $20 \mathrm{mg} \mathrm{l}^{-1}$, respectively, in a fermentation medium containing sucrose and urea. Subsequently, we have reported the cloning of the biotin biosynthesis gene cluster of SB304 and SB412 on a $7 \cdot 2 \mathrm{~kb}$ EcoRI-HindIII fragment and the recombinant strains constructed from the above two mutants showed a marked D-biotin 


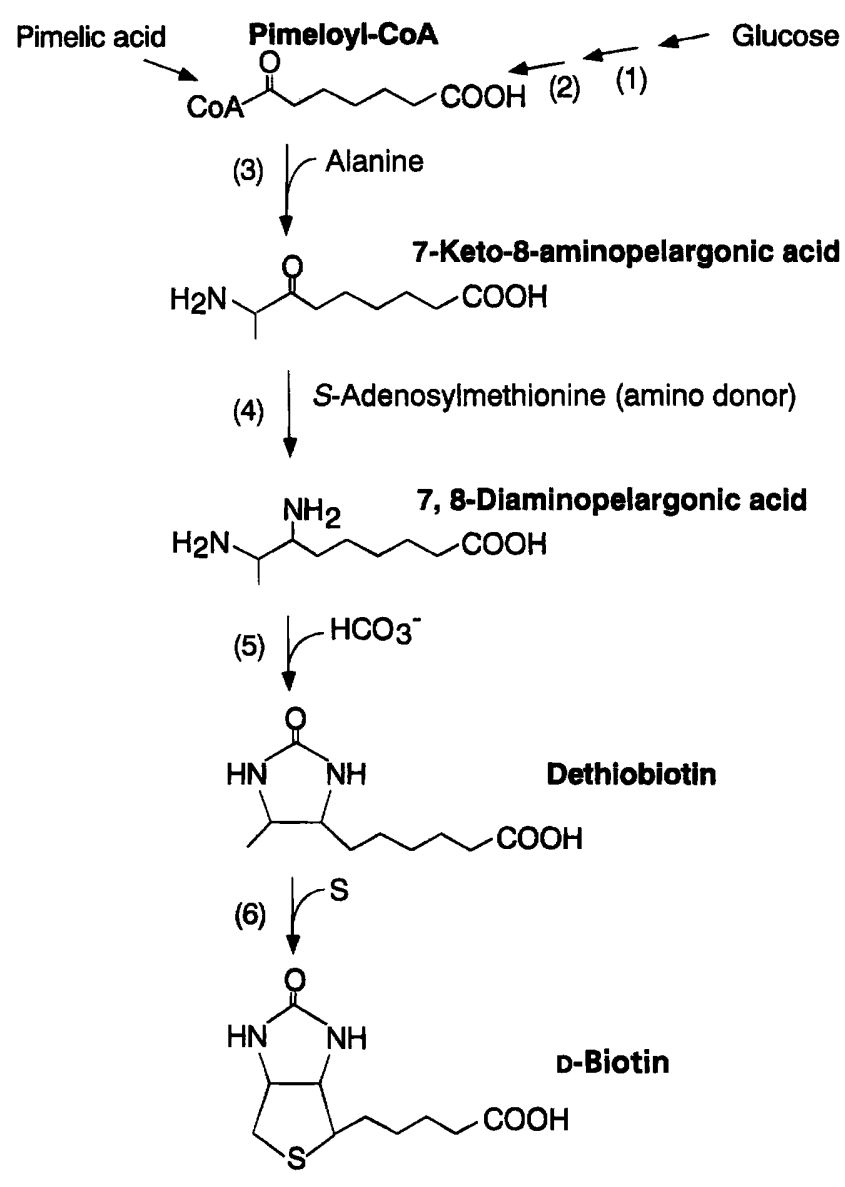

Fig. 1. Pathway of biotin biosynthesis in bacteria. (1) bioH, block before pimeloyl-COA; (2) bioC, block before pimeloylCOA; (3) bioF, KAPA synthase; (4) bioA, DAPA aminotransferase; (5) bioD, dethiobiotin synthase; (6) bioB, biotin synthase.

production (200 $\left.\mathrm{mg} \mathrm{l}^{-1}\right)$ (Sakurai et al., 1993b). Complementation of the $E$. coli biotin auxotrophs with deletion plasmids and analysis of $\operatorname{Tn} 1000$ insertion derivatives from these plasmids have revealed that the $S$. marcescens bio genes are clustered in the order bio $A B F C D$, and constitute an operon (Sakurai et al., 1993b).

There have been few genetic and enzymic findings on the regulation of D-biotin biosynthesis in $S$. marcescens. This paper deals with the gene structure and expression of the wild-type bio operon of $S$. marcescens.

\section{METHODS}

Strains, plasmids and media. Bacterial strains and plasmids used are shown in Table 1 . Nutrient medium containing $0.5 \%$ $(\mathrm{w} / \mathrm{v})$ glucose, $1.0 \%(\mathrm{w} / \mathrm{v})$ peptone, $0.3 \%(\mathrm{w} / \mathrm{v})$ meat extract, $1.0 \%(\mathrm{w} / \mathrm{v})$ yeast extract and $0.5 \%(\mathrm{w} / \mathrm{v}) \mathrm{NaCl}$ was used for routine colony isolation and growth study of $S$. marcescens strains. Luria-Bertani (LB) medium was used as a rich medium for E. coli strains. The minimal medium of Davis \& Mingioli (1950) was modified by omitting sodium citrate and increasing the glucose concentration to $0.5 \%(\mathrm{w} / \mathrm{v})$. Antibiotics were added at the following concentrations for $E$. coli: kanamycin $(\mathrm{Km}), 100 \mu \mathrm{g} \mathrm{ml}^{-1}$; ampicillin (Ap), $100 \mu \mathrm{g} \mathrm{ml}^{-1}$; streptomycin $(\mathrm{Sm}), 50 \mu \mathrm{g} \mathrm{ml}^{-1}$. For $S$. marcescens, $\mathrm{Km}$ and Ap were added at concentrations of 200 and $500 \mu \mathrm{g} \mathrm{ml}^{-1}$, respectively.

Primer-extension analysis. The $5^{\prime}$ ends of the bio $A$ and the bio $B$ transcripts were mapped by primer-extension analysis with primer PbioA1 (5'-GGGGTGCCAGATATGGCG-3') complementary to a region from position nt 2577 to 2594 of the mRNA transcript for bio $A$, and primer PbioB1 (5'-ATCAAACAGGGCCTGGGTCTT-3') complementary to a region from position nt 2759 to 2739 of the mRNA transcript for bioB. To facilitate the detection of extended products, pUC19-derived high-copy-number plasmids were used. Blunt-ended $1 \cdot 1 \mathrm{~kb}$ ScaI-PvuII fragments containing the bio $A$ and bioB promoters and the truncated $b i o A$ and $b i o B$ structural genes excised from pLGW101. This fragment was ligated with the $2.4 \mathrm{~kb} P v u I I$ fragment of pUC19 of which the tac promoter region was removed, producing plasmid pABP101. Total $S$. marcescens RNA was prepared from mid-exponential-phase cells of 8000(pABP101) grown in minimal medium with ampicillin. RNA was purified using the hot-phenol extraction procedure (Hinnebusch \& Fink, 1983) and $20 \mu \mathrm{g}$ RNA were mixed with 20 pmol $5^{\prime}$ end $\alpha-{ }^{32} \mathrm{P}$-labelled primer. The mixture was denatured at $80^{\circ} \mathrm{C}$ in $50 \mathrm{mM}$ PIPES $/ \mathrm{KOH}(\mathrm{pH} 6.4$ ), $0.4 \mathrm{M}$ $\mathrm{NaCl}$ containing $1 \mathrm{mM}$ EDTA and $50 \%$ formamide for $15 \mathrm{~min}$, and chilled on ice. Primers were hybridized with the RNA by incubating at $20^{\circ} \mathrm{C}$ for $16 \mathrm{~h}$. After ethanol precipitation, DNA-RNA hybrids were extended at $42^{\circ} \mathrm{C}$ for $60 \mathrm{~min}$ in $50 \mathrm{mM}$ Tris/ $\mathrm{HCl}$ (pH 8.3), $100 \mathrm{mM} \mathrm{KCl}, 10 \mathrm{mM} \mathrm{MgCl}, 1 \mathrm{mM}$ DTT, $1 \mathrm{mM}$ each of dGTP, dATP, dCTP and dTTP, 0.5 units human placental ribonuclease inhibitor (Promega) and 22 units Rous-associated virus (RAV-2) reverse transcriptase (Takara Shuzo). The products were separated on an $8 \%$ polyacrylamide sequencing gel. A dideoxy sequencing ladder was run in parallel for size comparison.

Subcloning and construction of lacZ fusions. For monitoring the expression of bio $A$ and bioB, lac $Z$ transcriptional/ translational fusions were constructed. Since amplification of the regulatory site of the genes in a high-copy-number plasmid might cause abnormal expression because of the absence of its repressor, we used pLGlacZ339, a low-copy-number promoter analysis vector, consisting of the $\mathrm{pSC101}$ replicon and the promoterless lacZ structural gene (Omori et al., 1991).

The $0.59 \mathrm{~kb}$ DNA fragments containing the bio promoter/ operator region and $5^{\prime}$ ends of both $b i o A$ and $b i o B$ structural genes (nt 2278-2834) were amplified by PCR from pLGW101. The primers used for this PCR were 5'-T'TGGA'TCC $($ Bam HI)CAGATCT (BglII)-ACCGCCACCGAACCAGAGTCCG-3' and $5^{\prime}$-TTTAGATCT(BglII)-CGGATCC(BamHI)-GCTGACGCGGGTCGAAGTCCTGG-3', both of which involve $B g I I$ and $B a m H I$ restriction sites in their $5^{\prime}$ ends (underlined sequences) to facilitate directional cloning. To construct the bio $A$-lac $Z$ fusion plasmids, the $0.59 \mathrm{~kb}$ PCR products were digested with $B g I I$ and ligated into the BamHI site of pLGlacZ339 to render the direction matching the bio $A$ transcription in-frame. The resultant lac $Z$ fusion, pZPA101, was fused with the lac $Z$ gene of pLGlacZ339 in-frame to the $5^{\prime}$ regions of the bio $A$ gene.

To construct the bioB-lac $Z$ fusion plasmids, the above $0.59 \mathrm{~kb}$ PCR products were digested with $B a m \mathrm{HI}$ and ligated into the $B a m \mathrm{HI}$ site to tender the direction matching the bioB transcription in-frame. The resultant lac $Z$ fusion, pZPB101, was fused with the lac $Z$ structural gene of pLGlacZ339 in-frame to the $5^{\prime}$ region of the $b i o B$ gene. The direction of the insert was 
Table 1. Strains and plasmids

\begin{tabular}{|c|c|c|}
\hline Strain/plasmid & Relevant genotype/phenotype* & Reference/source \\
\hline \multicolumn{3}{|l|}{ E. coli } \\
\hline MG1063 & $\mathrm{F}^{+}:: \operatorname{Tn} 1000 \operatorname{rec} A 56$ & Mark (1978) \\
\hline 3104ST & bio $A 24 \operatorname{rec} A 56 \mathrm{Sm}^{\mathrm{r}}$ & Sakurai et al. (1993b) \\
\hline 3105ST & bioB17 $\mathrm{rec} A 56 \mathrm{Sm}^{\mathrm{r}}$ & Sakurai et al. (1993b) \\
\hline $3106 \mathrm{ST}$ & bioF103 rec $A 56 \mathrm{Sm}^{\mathrm{r}}$ & Sakurai et al. (1993b) \\
\hline $3107 \mathrm{ST}$ & bioC18 $\operatorname{rec} A 56 \mathrm{Sm}^{\mathrm{r}}$ & Sakurai et al. (1993b) \\
\hline $3108 \mathrm{ST}$ & bioD19 recA56 $\mathrm{Sm}^{\mathrm{r}}$ & Sakurai et al. (1993b) \\
\hline \multicolumn{3}{|l|}{ S. marcescens } \\
\hline 8000 & Wild-type of S. marcescens Sr41 & Matsumoto et al. (1973) \\
\hline TT392 & $\mathrm{Nuc}^{-} \mathrm{r}^{-} \mathrm{Ap}^{\mathrm{s}} \mathrm{Km}^{\mathrm{s}}$ & Takagi \& Kisumi (1985) \\
\hline \multicolumn{3}{|l|}{ Plasmids } \\
\hline pBR322 & $A p^{r} T c^{r}$ & Boliver et al. (1977) \\
\hline pUC19 & $A p^{r}$ & Yanisch-Perron et al. (1985) \\
\hline pLG339 & $\mathrm{Km}^{\mathbf{r}} \mathrm{Tc}^{\mathrm{r}}$ & Stoker et al. (1982) \\
\hline pHSG298 & $\mathrm{Km}^{\mathrm{r}}$ & Takeshita et al. (1987) \\
\hline pHSG299 & $\mathrm{Km}^{\mathrm{r}}$ & Takeshita et al. (1987) \\
\hline pLGlacZ339 & $\begin{array}{l}\mathrm{Km}^{\mathrm{r}} \text {, pSC101 replicon, truncated lacZ structural gene lacking the promoter } \\
\text { and Shine-Dalgarno region }\end{array}$ & Omori et al. (1991) \\
\hline pLGW101 & $\mathrm{Km}^{\mathrm{r}}, \mathrm{pLG} 339::$ bio $A B F C D$ & Sakurai et al. (1993b) \\
\hline pLGW101dA3 & pLGW101-derivative bio $A:: \operatorname{Tn} 1000$ & This work \\
\hline pLGW101dB7 & pLGW101-derivative bioB:: $\operatorname{Tn} 1000$ & This work \\
\hline pLGW101dF26 & pLGW101-derivative bioF: : $\operatorname{Tn} 1000$ & This work \\
\hline pLGW101dC26 & pLGW101-derivative bioC:: $\operatorname{Tn} 1000$ & This work \\
\hline pLGW101dD18 & pLGW101-derivative bioD: : $\operatorname{Tn} 1000$ & This work \\
\hline pABP101 & $\begin{array}{l}\mathrm{Ap} \mathrm{p}^{\mathrm{r}}, \mathrm{pUC} 19 \text { with wild-type bio promoter/operator and truncated bio } A \text { and } \\
\text { bioB genes }\end{array}$ & This work \\
\hline pZPA101 & $\begin{array}{l}\mathrm{Km}^{\mathrm{r}} \text {, pLGlacZ339 with } 590 \text { bp wild-type bio } A \text { promoter fragment and part } \\
\text { of bio } A \text { fused to lac } Z \text { structural gene }\end{array}$ & This work \\
\hline pZPB101 & $\begin{array}{l}\mathrm{Km}^{\mathrm{r}} \text {, pLGlacZ339 with } 590 \mathrm{bp} \text { wild-type bioB promoter fragment and part } \\
\text { of bioB fused to lacZ structural gene }\end{array}$ & This work \\
\hline
\end{tabular}

*Symbols used for relevant genotypes and phenotypes are as follows: $\mathrm{Nuc}^{-}$, no production of extracellular nuclease; $\mathbf{r}^{-}$, defect of host restriction enzymes; $A p^{r}$, resistance to ampicillin; $\mathrm{Km}^{\mathrm{r}}$, resistance to kanamycin; $\mathrm{Sm}^{\mathrm{r}}$, resistance to streptomycin; Tc ${ }^{\mathrm{r}}$, resistance to tetracycline; $\mathrm{Ap}^{\mathrm{s}}$, enhanced sensitivity to ampicillin; $\mathrm{Km}^{\mathbf{s}}$, enhanced sensitivity to kanamycin.

confirmed by restriction analysis and their junctions were verified by nucleotide sequencing.

Monitoring $\beta$-galactosidase activities in cells containing the bio-lacZ fusion plasmids. The bio-lac $Z$ translational fusion plasmids described above were introduced into $S$. marcescens TT392, a wild-type strain for biotin biosynthesis, using electrotransformation (Sakurai et al., 1996). Transformants were grown at $30^{\circ} \mathrm{C}$ to the mid-exponential phase in $3 \mathrm{ml}$ minimal medium containing kanamycin in the presence or absence of $1 \mu \mathrm{M}$ D-biotin. Cells were collected by centrifugation at $12000 \mathrm{~g}$ for $10 \mathrm{~min}$ at $4^{\circ} \mathrm{C}$. Cell pellets were resuspended in $20 \mathrm{mM}$ Tris $/ \mathrm{HCl}$ ( $\mathrm{pH} \mathrm{8.0)}$ buffer and disrupted by sonication on an ice bath. The resultant cell lysates were used for the assay of $\beta$-galactosidase activities, using ONPG as substrate (Miller, 1972). One unit $\beta$-galactosidase activity formed $1 \mathrm{nmol}$ products $\mathrm{min}^{-1}$ (mg protein) ${ }^{-1}$.

Sequence analysis. The DNA sequence of the plasmid containing the wild-type $S$. marcescens bio operon was determined by the dideoxy chain-termination method (Sanger et al., 1977) with templates prepared from DNA subcloned in pHSG298 and
pHSG299 using universal primers. Ordered deletion subclones were obtained by unidirectional digestion (Yanisch-Perron et al., 1985) using the Kilo-Sequence Deletion Kit ('Takara Shuzo). Synthetic primers were used to complete the sequence with the same templates as the double-stranded template.

Computer analysis of the sequence was done with the GENETYX software (Software Development) and CLUSTAL v (Higgins et al., 1988). For homology studies on amino acid sequences, the international protein and nucleotide databases (GenBank, EMBL and DDBJ) were searched on-line using the TFASTA program on the host computer of DDBJ (Pearson \& Lipman, 1988).

In vitro transcription/translation analysis. In vitro transcription/translation reactions were carried out with S-30 extracts prepared from $S$. marcescens 8000 according to DeVries \& Zubay (1967). Reaction mixture contained $0.4 \mu \mathrm{g}$ purified pLGW101, $10 \mu \mathrm{g} \mathrm{S}-30$ extract and $1000 \mu \mathrm{Ci}(37 \mathrm{MBq}) \mathrm{L}-\left[{ }^{35}\right.$ S $]$ methionine in a total volume of $5 \mu \mathrm{l}$. The resulting labelled products were separated by SDS-PAGE (12.5\%; Laemmli, 1970) and visualized by autoradiography. 
Disruption of the bio genes by Tn 1000 insertion. Plasmid pLGW101, a low-copy-number plasmid carrying the entire bio operon, was used in this experiment to avoid segregational and structural instability. Each of the bio genes on pLGW101 was disrupted by transposon $\operatorname{Tn} 1000$ insertion as described by Sakurai et al. (1993b). Strain MG1063(pLGW101) was mated with E. coli $3104 \mathrm{ST}$, 3105ST, 3106ST, 3107ST or 3108ST. $\mathrm{Km}^{\mathrm{r}}$, $\mathrm{Sm}^{\mathrm{r}}$ and $\mathrm{Tc}^{\mathrm{r}}$ transconjugants were selected on plates and tested for each of the $\mathrm{Bio}^{-}$phenotypes. The plasmids were extracted from the transconjugants and the sites of $\operatorname{Tn} 1000$ insertions were determined by restriction analysis.

Determination of the $\mathbf{N}$-terminal amino acid sequence. Cells of T'T392(pZPA101) and T'T392(pZPB101) were harvested from exponentially growing cultures in minimal medium. Cell extracts were purified as described above. LacZ fusion proteins were purified using ProtoSorb lac $Z$ Immunoaffinity Adsorbent kit (Promega) according to the manufacturer's instructions. Purified proteins were subjected to SDS-PAGE and transferred electrophoretically to Immobilon-P membranes (Millipore) in $25 \mathrm{mM}$ Tris $/ \mathrm{HCl}$ (pH 8.3) $/ 1920 \mathrm{mM}$ glycine $/ 10 \%$ (v/v) methanol. The transferred proteins corresponding to BioA-and BioB-LacZ fusions were excised from the membrane and analysed on a gas-phase sequenator (Hewlett Packard model HP G1005A).

Other genetic procedures and recombinant DNA techniques. Standard procedures were used for plasmid preparation, restriction enzyme digestion, ligation and agarose gel electrophoresis (Maniatis et al., 1982). Cells of E. coli and S. marcescens were transformed using the method of Maniatis et al. (1982) and by electroporation as described by Sakurai \& Komatsubara (1996), respectively.

Protein determinations. Protein concentration was determined using a Bio-Rad protein assay kit and BSA as the standard (Bradford, 1976).

\section{RESULTS}

\section{Sequencing of the S. marcescens bio operon}

We have reported that the $S$. marcescens bio genes form an operonic structure (Sakurai et al., 1993b). The $7 \cdot 2 \mathrm{~kb}$ EcoRI-HindIII fragment of pLGW101 contains the entire wild-type bio operon coding region (nt 1353-6331). Analysis of this nucleotide sequence has revealed one ORF and four tandem ORFs (GenBank/EMBL/DDBJ accession no. D17468). The deduced molecular mass of the five gene products are 46986 (425 amino acid), 38569 (346 aa), 41083 (382 aa), 27776 (255 aa) and $246557 \mathrm{Da}$ (227 aa), respectively. The proximity and common orientation of the products of the $S$. marcescens bio genes have suggested that these genes constitute a typical bacterial operon. Subsequently, we constructed deletion derivatives of the $7.2 \mathrm{~kb}$ DNA fragment and examined them for complementation test using $E$. coli bio auxotrophs, confirming that the above five ORFs correspond to the bio $A,-B,-F,-C$ and $-D$ genes, respectively (data not shown). Although the bio $A$ transcription is independent of the bioBFCD transcription, both bio $A$ and bio $B$ transcriptions are coordinately repressed by a common operator sequence as shown below. Hence, we defined bio $A$ as a member of the $S$. marcescens bio operon as in $E$. coli. The nucleotide sequence confirmed that the gene encoding the first ORF corresponding to that of the E. coli
BioA (DAPA aminotransferase) is transcribed in the opposite direction to the other four genes. This structure is very similar to that of the $E$. coli bio operon (Otsuka $e t$ al., 1988). The remaining four genes encoding BioB (biotin synthase), BioF (KAPA synthase), BioC (an enzyme responsible for pimeloyl-CoA formation) and BioD (dethiobiotin synthase) are coordinately transcribed as a polycistron from a single promoter located between the bio $A$ and $b i o B$ genes. The first ORF corresponding to BioA extends from an ATG initiation codon at position 2630 to an ATT termination codon at position 1353. The second ORF corresponding to BioB starts from an ATG codon at nt 2716 and is terminated by a TGA stop at codon nt 3756. The initiation site of the third ORF (BioF, KAPA synthase) is ATG of nt 3756 and the termination is TGA at nt 4904. The fourth ORF corresponding to BioC starts from ATG at nt 4888 and to TAA at nt 5655 . The last, encoding BioD (dethiobiotin synthase), extends from a GTG (Val) codon at nt 5648 and is terminated by TGA codon at nt 6331 .

The above five ORFs are preceded by sequences with homology to the $3^{\prime}$ end of $16 \mathrm{~S}$ rRNA and presumably represented RBSs (Ringquist et al., 1992). At the $3^{\prime}$ ends of the bio $A$ and bioD genes, regions of dyad symmetries with calculated $\Delta G$ (Gibbs free energy) values of $-18.3 \mathrm{kcal} \mathrm{mol}^{-1}\left(-76.9 \mathrm{~kJ} \mathrm{~mol}^{-1}\right)$ and $-29.8 \mathrm{kcal} \mathrm{mol}^{-1}\left(-125.2 \mathrm{~kJ} \mathrm{~mol}^{-1}\right)$ are formed between positions at nt 1341-1313 (5'-TGCTGGTCCAGATAGCGGGCCAGCA-3') and at nt 6351-6380 (5'CAACGCCGGGTCTTATGACCGGCGTTG-3'). The later sequence is followed by four thymidine residues and resembles a $\rho$-independent transcription termination signal (Rosenberg \& Court, 1984).

\section{Comparison of S. marcescens bio operon products with other proteins}

The deduced amino acid sequences of the bio operons were used for searching the GenBank, EMBL and DDBJ databases using the TFASTA program. The $S$. marcescens BioA is very similar to that of E. coli $(71.5 \%$ identity in 424 aa overlap) and Bacillus sphaericus BioA (35.8\% identity in 436 aa overlap). BioA has a high sequence similarity (up to $20 \%$ identity) to the extensive family of eukaryotic ornithine aminotransferase.

The $S$. marcescens BioB shows significant similarity with the E. coli BioB (86.5\% identity in 346 aa overlap), Saccharomyces cerevisiae biotin synthase $(49.3 \%$ identity in 294 aa overlap), Brevibacterium flavum biotin synthase (34.8\% identity in 299 aa overlap) and B. sphaericus (33.6\% identity in 304 aa overlap). The BioB protein has a local homology with the E. coli lip $A$ product $(16.0 \%$ identity in 238 aa overlap), which catalyses the sulfur incorporation to octanoic acid involved in lipoic acid synthesis. BioB (biotin synthase) is involved in the insertion of sulfur into dethiobiotin. The sequence similarity between the $l i p A$ and $b i o B$ products suggests that a common sulfur donor and/or a common reaction mechanism are involved in both biotin and lipoic acid biosynthesis. 


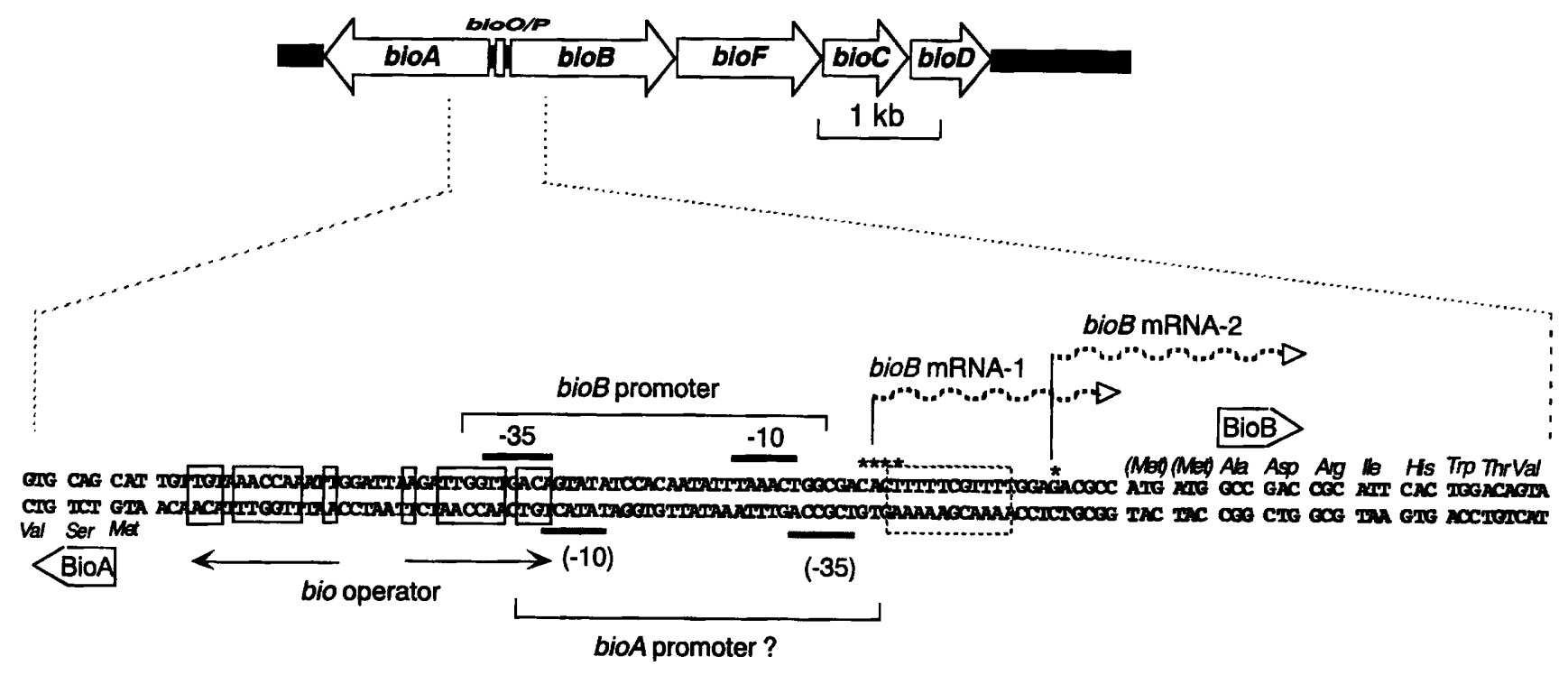

Fig. 2. Promoter/operator region of the $S$. marcescens bio operon. The upper part of the diagram depicts the relative positions of the five bio genes. Asterisks represent transcription initiation sites. Waved arrows indicate the transcripts. Dashed-wave arrows indicate the bioB multi transcripts. Solid arrows represent the location of an imperfect palindrome (putative operator).

The scan of the amino acid sequences of $S$. marcescens BioF (KAPA synthase) against the protein databases has revealed that $S$. marcescens BioF has a similarity with the $E$. coli $(64.8 \%$ identity in 383 aa overlap) and B. sphaericus ( $30.5 \%$ identity in 383 aa overlap) BioF proteins.

Significant similarity of $S$. marcescens $\mathrm{BioC}$, involved in the formation of pimeloyl-CoA, was observed with the bioC product of E. coli (52-2\% identity in 248 aa overlap).

BioD catalyses the formation of ureide ring by transcarboxylation of DAPA into dethiobiotin. Computer searches did not find proteins having significant homology with $S$. marcescens BioD except $E$. coli and $B$. sphaericus BioDs (74.2 and 35.1\% identities in 213 and 191 aa overlaps, respectively).

\section{Structure and transcription initiation sites of the bio promoters}

A computer search for the bio $A$ promoter sequence has revealed two conserved sequences: TCGCCA (nt 26922687) and TATACT (nt 2670-2665), corresponding to -35 and -10 (Pribnow box) regions, respectively. For the bioB promoter, TTGACA (nt 2660-2665) and TAAACT (nt 2682-2687), were found in the complementary sequence, respectively (Fig. 2 ). It is possible that these sequences, which are similar to the consensus sequence of $E$. coli promoters, constitute the divergently transcribed promoters of the $S$. marcescens bio operon. The bio $A$ and bio $B$ genes are apparently controlled by a single regulatory region: a putative $32 \mathrm{bp}$ operator (nt 2634-2665), common to both bio $A$ and bioB promoters, containing an imperfect palindromic sequence that partially overlaps the $b i o B$ promoter (Fig. 2).
To confirm the predicted promoter/operator structure, primer-extension analysis was used to locate the transcription initiation sites of the bio $A$ and $b i o B$ (or bioBFCD) genes. The promoter regions of the $b i o A$ and $b i o B$ genes were subcloned into a pUC-derivative vector, which produces the $5^{\prime}$ region of the bio $A$ and bioB mRNAs but does not affect cell growth because it lacks most of the structural genes. Synthetic oligonucleotides complementary to the $5^{\prime}$ region of the bio $A$ or bioB transcripts were synthesized as primers. The primer-extension analysis using the RNA from $S$. marcescens 8000 containing pABP101 carrying the wild-type bio promoter has revealed that the transcript for the bioB gene (right transcription) starts primarily 22 bases upstream from the ATG codon or seven bases downstream from the Pribnow box, in agreement with the consensus start point defined by the above predicted promoter (Fig. 3). An additional band was observed at a position located at six bases upstream (G, nt 2710) from the ATG start codon. We could not obtain a clear extended product of the bio $A$ gene because of the possible instability.

\section{Analysis of the regulation of bio expression using bio-lacZ transcriptional-translational fusions}

Transcriptional regulation of the bio operon was examined. No quantitative assay method has been reported for biotin synthase (the bioB gene product). Thus, to normalize the promoter activity of both directions, we constructed $\operatorname{lac} Z$ fusion plasmids of the $\operatorname{bio} A$ and $b i o B$ genes, pZPA101 and pZPB101, respectively, and analysed the activities of $\beta$-galactosidase (LacZ) in the wild-type strain carrying these plasmids. LacZ activities of both S. marcescens 8000 (pZPA101) and 8000 (pZPB101) were strongly repressed by the addition of $1 \mu \mathrm{M}$ D-biotin to the 


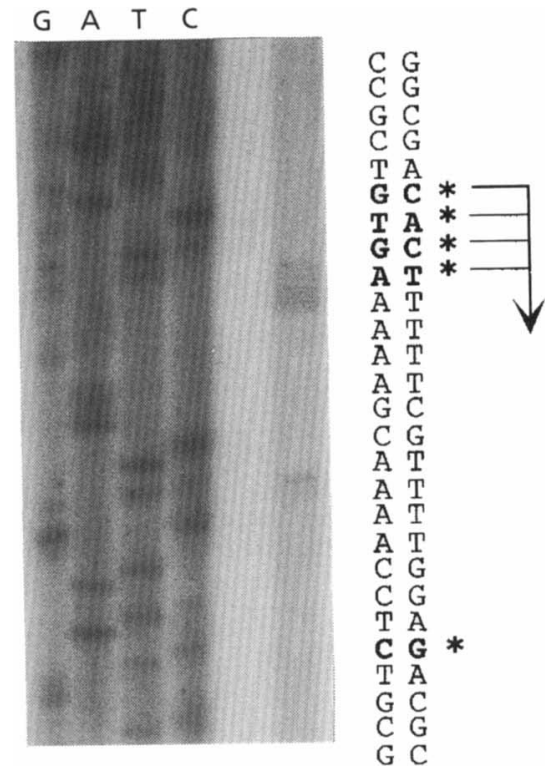

Fig. 3. Mapping of the $5^{\prime}$ end of the bioB mRNA. Primer extension was performed with RNAs isolated from $S$. marcescens 8000(pABP101), containing the bio promoter/ operator region and the truncated bio $A$ and bio $B$ genes. Primer-extension products and a sequencing ladder generated with the same primer used in the extension mapping were run in parallel on denaturing $5 \%$ polyacrylamide gels. Asterisks indicate the positions of the major and minor extension products.

culture medium (Table 2). Note that these lac $Z$ fusions contain the authentic Shine-Dalgarno sequences and the ATG start sites for the $S$. marcescens bio genes.

\section{Identification of the bio gene products}

To determine the sizes of the bio operon products encoded by pLGW101, carrying the $7 \cdot 2 \mathrm{~kb}$ DNA fragment encoding the entire bio operon, we used an in vitro transcription/translation experiment using $\left[{ }^{35} \mathrm{~S}\right]$ methionine. Polypeptides specific to the bio genes were ex- (a)

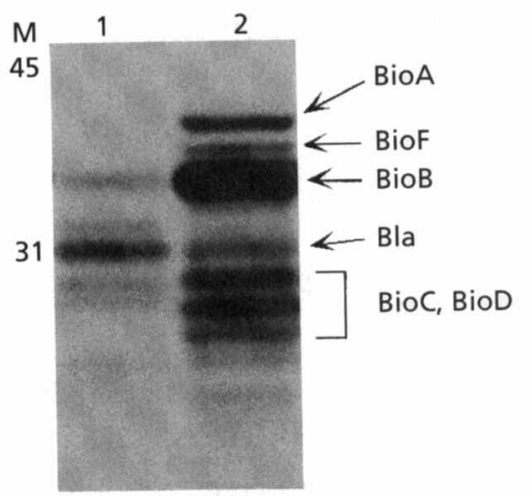

(b)

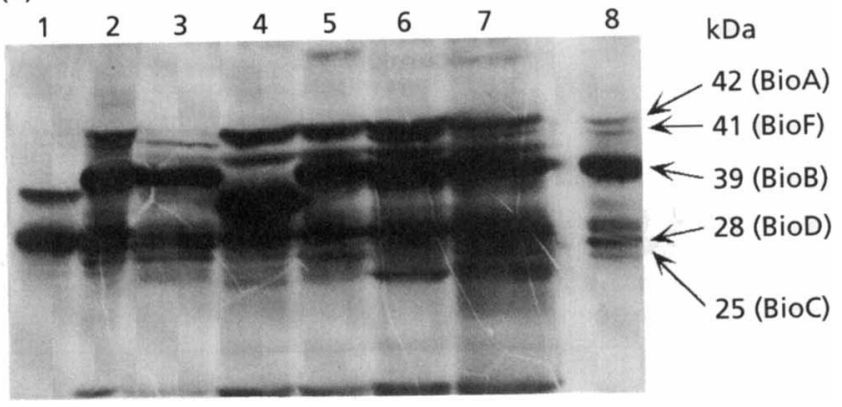

Fig. 4. (a) SDS-PAGE of ${ }^{35}$ S-labelled polypeptides encoded by the wild-type bio genes. Plasmid-specified polypeptides were synthesized with an S-30 cell-free extract from $E$. coli. The ${ }^{35}$ S-labelled polypeptides were analysed by SDS-PAGE and visualized by autoradiography. The positions of protein standards (M) of 42 and $30 \mathrm{kDa}$ are indicated. Bla indicates $\beta$-lactamase encoded by the plasmid used. Lanes: 1, pBR322 (vector); 2, pLGW101. (b) SDS-PAGE of ${ }^{35}$ S-labelled polypeptides encoded by pLGW101-derivatives of which bio genes were disrupted with Tn1000 insertions. Lanes: 1, pLG339 (vector); 2 , pLGW101; 3, pLGW101dA3; 4, pLGW101dB7; 5, pLGW101dF26; 6, pLGW101dC26; 7, pLGW101dD18; 8, pLGW101.

pressed from plasmid pLGW101. Molecular masses calculated by these migrations were approximately 42,41 , 39,28 and $25 \mathrm{kDa}$ (Fig. 4). Products of 41, 39, 28 and $25 \mathrm{kDa}$ correspond to $\mathrm{BioF}, \mathrm{BioB}, \mathrm{BioC}$ and $\mathrm{BioD}$ on the

Table 2. Specific $\beta$-galactosidase activities of bio-lacZ fusions

Cells were grown in minimal medium in the presence or absence of $1 \mu \mathrm{M}$-biotin. pZPA101 and pZPB101 are the bio $A$ - and bioB-lacZ translational fusion plasmids, respectively. One unit $\beta$ galactosidase activity formed $1 \mathrm{nmol}$ products $\min ^{-1}(\mathrm{mg} \text { protein })^{-1}$. Values represent the means of two independent assays.

\begin{tabular}{|lccc|}
\hline Strain & Promoter & \multicolumn{2}{c|}{ Specific activity (units) } \\
\cline { 3 - 4 } & & -D-Biotin & +D-Biotin \\
& & & \\
\hline TT392 & No plasmid & $<10$ & $<10$ \\
TT392(pLGlacZ339) & Vector plasmid & 46 & 45 \\
TT392(pZPA101) & bio $A$ & 190 & 30 \\
TT392(pZPB101) & bio $B$ & 610 & 65 \\
\hline
\end{tabular}


basis of the molecular masses deduced from amino acid sequences. The size of a $42 \mathrm{kDa}$ protein, which is close to BioA, but is somewhat larger than that of the expected molecular mass of BioA (425 aa, $47 \mathrm{kDa}$ ).

To locate the bio operon gene products, proteins encoded by pLGW101 and its derivatives mutagenized with transposon $\operatorname{Tn} 1000$ were labelled with $\left[{ }^{35} \mathrm{~S}\right]$ methionine, and the synthesized products were analysed by SDSPAGE, followed by fluorography (Fig. 4b).

pLGW101dA3 (BioA ${ }^{-}$) produced no $42 \mathrm{kDa}$ protein, whereas other proteins seen in PLGW101 were produced, suggesting that the $42 \mathrm{kDa}$ protein is actually the bio $A$ gene product (Fig. 4b, lane 3). Migrations of other products except for BioA were not affected by bio $A$ disruption, indicating that the bio $A$ gene transcription might be independent of other bio genes. When pLGW101dF26, a plasmid in which the Tn1000 insertion inactivated the bio $F$ gene, was used as a template, the $41 \mathrm{kDa}$ protein was not observed, suggesting that this protein is the bioF gene product (Fig. 4b, lane 5). A smaller band of $27 \mathrm{kDa}$ might be the truncated BioF. pLGW101dB7 $\left(\mathrm{BioB}^{-}\right)$did not produce the band of $39 \mathrm{kDa}$, but yielded a smaller truncated polypeptide (Fig. $4 \mathrm{~b}$, lane 4). In addition, bands of 41,28 and $25 \mathrm{kDa}$ which correspond to $\mathrm{BioF}, \mathrm{BioD}$ and $\mathrm{BioC}$, respectively, faded because of the polar effect of $\operatorname{Tn} 1000$ insertion.

$\operatorname{Tn} 1000$ insertion in pLGW101dC26 $\left(\mathrm{BioC}^{-}\right)$yielded the possible BioC truncated form of approximately $27 \mathrm{kDa}$ (Fig. 4b, lane 6). pLGW101dD18, in which Tn1000 disrupted bioD allele, did not produce the $28 \mathrm{kDa}$ polypeptide (Fig. 4b, lane 7). The molecular mass of BioD $(25 \mathrm{kDa})$ calculated from the nucleotide sequence is expected to be smaller than that of BioC $(28 \mathrm{kDa})$. However, the band of $\mathrm{BioC}$ in this analysis was apparent to be smaller than that of BioD.

In pLGW101dB7 (BioB $\left.{ }^{-}\right)$, pLGW101dF26 (BioF $\left.{ }^{-}\right)$and pLGW101dC26 $\left(\mathrm{BiOC}^{-}\right)$, the band corresponding to each disrupted gene disappeared with the Tn1000 insertion. In addition, bands of the peptides $(\mathrm{BioF}, \mathrm{BioC}$ and $\mathrm{BioD}$ in pLGW101dB7; BioC and BioD in pLGW101dF26; BioD in pLGW101dC26) also disappeared because of a polar effect caused from $\operatorname{Tn} 1000$ insertions. This result confirmed that the $b i o B, b i o F, b i o C$ and bioD genes might constitute a single cistron in this order.

$\mathrm{N}$-terminal amino acid sequences of $\mathrm{BioA}$ and $\mathrm{BioB}$ were attempted to be determined. BioA-LacZ and BioB-LacZ fusions were purified by LacZ-immunoaffinity chromatography from TT392 cells carrying pZPA101 and pZPB101, respectively. Elutions containing purified LacZ fusions from the immunoaffinity column contained one major protein band with a molecular mass of about $115 \mathrm{kDa}$ corresponding to that of $\mathrm{LacZ}$ (data not shown). $\mathrm{N}$-terminal sequencing of the first five residues of the BioB-LacZ fusion showed that it begins A-D-R-I-H, not in agreement with the predicted start sequence (M-M-AD-R-I-H). We were unable to determine the N-terminal sequence of native BioA because of apparent $\mathrm{N}$-terminal blockage or a small quantity of the protein obtained.

\section{DISCUSSION}

The bio $A B F C D$ genes constitute an operon in $S$. marcescens as in $E$. coli. Nucleotide sequence analysis has revealed that the structure of this operon in $S$. marcescens is similar to that in E. coli. Comparison of the bio $A B F C D$ gene products of $S$. marcescens with those of $E$. coli demonstrated $71 \cdot 5,86 \cdot 5,64 \cdot 8,52 \cdot 2$ and $74 \cdot 2 \%$ similarity, respectively. $S$. marcescens differs from $E$. coli in the gene structure downstream of the bio $A$ region. Otsuka et al. (1988) have reported that in $E$. coli the bio $A$ gene has no terminator sequence and a short ORF is located after the bio $A$ coding region whose function has been unknown but possibly this ORF and the bio $A$ gene constitutes an operon. Nevertheless, in S. marcescens, we have found that no ORF follows the bio $A$ coding region and no significant homology with the ORF gene of $E$. coli in the corresponding nucleotide region of $S$. marcescens. This finding indicates that the unknown ORF of E. coli might not take part in the biotin biosynthesis.

S. marcescens BioB shows a low similarity to LipA as does E. coli BioB (Hayden et al., 1992). LipA catalyses the sulfur introduction into octanoic acid to produce lipoate. The catalytic function of LipA is apparently similar to that of BioB which catalyses the insertion of sulfur into dethiobiotin. We have then aligned the sequence of $E$. coli LipA with those of biotin synthases of five different micro-organisms (Fig. 5). We found that there are three highly homologous regions between the five biotin synthases and E. coli LipA : namely, motif I [C-x-x-x-C-x$\mathrm{x}-\mathrm{C}, \mathrm{C}-\mathrm{P}-\mathrm{E}-\mathrm{D}-\mathrm{C}-\mathrm{x}-(\mathrm{Y}, \mathrm{F})-\mathrm{C}$ for biotin synthase] which contains three cysteine residues; motif II [(Y, F)-N-H-N$(\mathrm{L}, \mathrm{I})$ ]; and motif III [S-G-x-(I, M)-(I, L, V)-G-(L, M)-(G, $\mathrm{K})-\mathrm{E}-(\mathrm{S}, \mathrm{T})]$. Since the $E$. coli $\mathrm{LipA}$ has regions less homologous with the entire region of biotin synthase except the above three regions, the three motifs were predicted to be of great significance for the sulfurintroduction reaction. Moreover, several hydrophobic amino acid residues are highly conserved between the five BioBs and LipA proteins (boxed in Fig. 5), suggesting that hydrophobicity might be needed for the catalytic function of BioB.

Cysteine residues generally provide ligands for iron atoms in iron-sulfur proteins via such a motif as $\mathrm{C}-\mathrm{x}-\mathrm{x}-\mathrm{C}-\mathrm{x}-\mathrm{x}-\mathrm{C}$ in bacterial ferredoxins (Lovenberg, 1973). Clusters containing three cysteine residues are known to be ironbinding motifs and are frequently found in oxidoreductases. We have found that the culture of an $S$. marcescens $\mathrm{D}$-biotin-producing strain in the presence of excess amounts of $\mathrm{Fe}^{2+}$ resulted in the significant increase of the D-biotin production (Masuda et al., 1995). In addition, D-biotin is apparently an oxidized form of dethiobiotin since the oxidation number of $\mathrm{D}$-biotin is greater than that of dethiobiotin. Hence, it is assumed that these three cysteine residues might bind to an iron atom to catalyse an oxidative introduction of sulfur atom into the inactive $\mathrm{C}-\mathrm{H}$ bonds of dethiobiotin. Recently, the E. coli $B i o B$ protein has been reported to have two irons and two sulfurs within the molecule: $\mathrm{BioB}$ is a $[2 \mathrm{~S}-2 \mathrm{Fe}]$ protein (Sanyal et al., 1994a). 


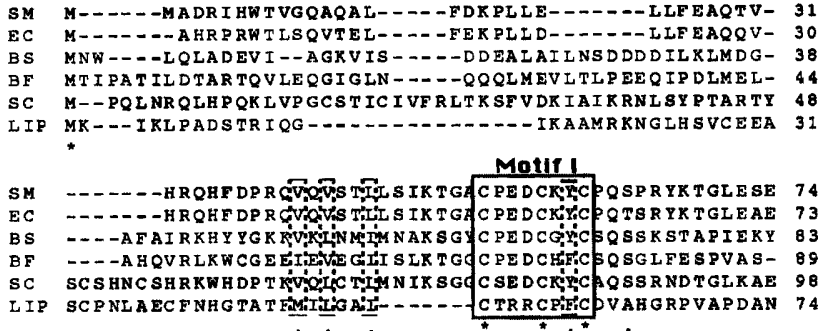

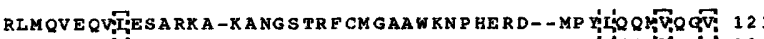

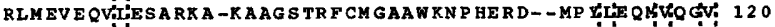

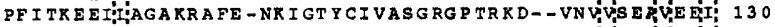
VWL DI P NLVEAAXOTAK - TGATEF DF VAAVKG PDERL- -MT CITE ERVL A'I 136

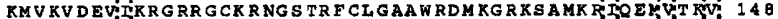

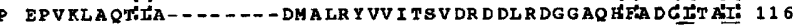

$$
\text { Motif II }
$$

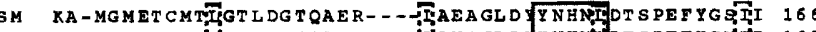
KA - MGIEACM KAK YGIXVCACH US ND

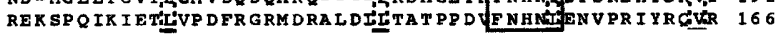
Moiurus."

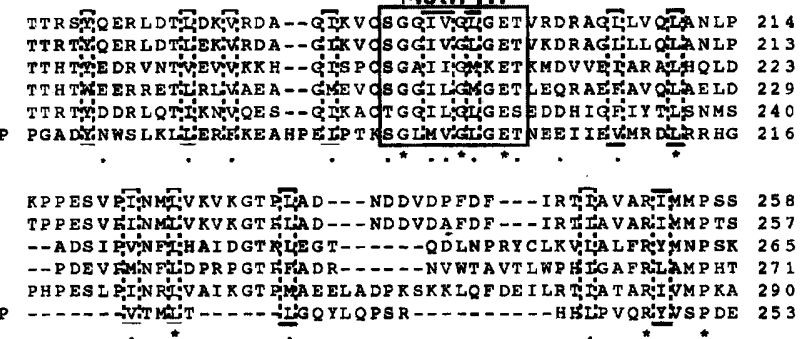

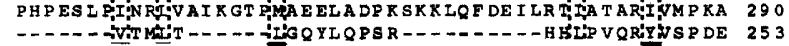

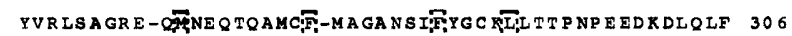
YVR LS A GRE - CANE Q TQAMCFF-MA GANS IFYYGC KLLT T T P NPE EDXDLQLF 305 EIR IS G GRE VNLG- - FLOPAGL YAANS IFVG - LYTI TTEGOEANS DYRML 311 MLRFA G GRELTLIGDXGSEQAT-L GOI NAMIVG - NYLT TTLGR PMEDDLDMM 319 II R LA A GR Y - TYKE T EOFVCFF-M A GC NS ITPTGK PMTL TT I YNGWDEDKAML 338

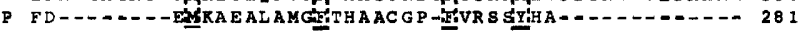

SM RKL QUN PQQTATEHG DNQQOOVLAKOLLNADTAEF Y NAAPEC RKL GLN PQQTAVLAGDNEQQQRLEQALMTP DT DEY YNAAAI BS EDL GFश IEDRI CLP IX - . AKNQIIOPMEA IP -- LISAKGMEV -

Fig. 5. Multiple amino acid sequence alignment for $S$. marcescens BioB (SM; Otsuka et al., 1988), E. coli BioB (EC), B. sphaericus BioB (BS; Osawa et al., 1989), Brev. flavum BioB (BF; Hatakeyama et al., 1992), Sacc. cerevisiae BIO2 (SC; Zhang et al., 1994) and $E$. coli LipA (LIP; Hayden et al., 1992). Identical residues are indicated by asterisks. Conserved residues are indicated by dots. Boxed regions indicate highly conserved motives between BioBs and LipA. F, I, M, L, V, Y and $W$ are defined as hydrophobic amino acids.

The promoter/operator region of the $S$. marcescens bio operon is very similar to those of other enteric bacteria: Citrobacter freundii, Salmonella typhimurium and E. coli (Shiuan \& Campbell, 1988). These operons are divergently transcribed leftward to the $\operatorname{bio} A$ gene and rightward to the bioBFCD genes. Primer-extension analysis showed multi-extended products for the bioB gene. We do not know whether this additional band represents the real start site or whether it is a simple artefact due to a premature stop during reverse transcription. It should be noted that no possible promoter sequences corresponding to these additional start sites are found by analogy with $E$. coli and other bacteria. Interestingly, the additional start site for bioB gene was observed in the region four bases downstream of the characteristic T-rich cluster (TTTTTCGTTTT, nt 2696-2706) (Fig. 2).

We tentatively identified an ORF of $1275 \mathrm{bp}$ as a coding region for the bio $A$ gene followed by a potential RBS (AA, nt 2626 to 2627) located 4 bp upstream of the ATG start codon (nt 2480). However, the migration of the expected BioA (42 kDa) on SDS-PAGE analysis was less than that of the predicted ORF sequence $(47 \mathrm{kDa})$. Although estimates of polypeptide size from SDS-PAGE are often inaccurate, the RBS proposed for the bio $A$ gene is not highly complementary to published sequences (Ringquist et al., 1992). Interestingly, a sequence having consensus to a bacterial RBS (GGTG, nt 2487-2490) followed by ATG sequence with a 6 bp space is located $151 \mathrm{bp}$ downstream in which there is a potential ORF starting from nt 2480 to 1356 , encoding of 376 aa. If BioA starts from this downstream ATG codon, the calculated molecular mass is $41378 \mathrm{Da}$, which is close to that found by SDS-PAGE. Unfortunately, we could not determine the $\mathrm{N}$-terminal amino acid sequence of BioA in the present study. Work is in progress to identify the real transcriptional features and the functional polypeptide of the $b i o A$ gene.

\section{ACKNOWLEDGEMENTS}

We thank Drs I. Chibata and T. Tosa for encouragement. We also thank Dr K. Omori for helpful discussion.

\section{REFERENCES}

Bachmann, B. J. (1990). Linkage map of Escherichia coli $\mathrm{K}-12$, edition 8. Microbiol Rev 54, 130-194.

Barker, D. F. \& Campbell, A. (1981). Genetic and biochemical characterization of bir $A$ gene and its product: evidence for a direct role of biotin holoenzyme synthetase in repression of the biotin operon in Escherichia coli. J Mol Biol 153, 469-492.

Boliver, F., Rodriguez, R. L., Greene, P. J., Betlach, H. L., Heynecker, H. W., Boyer, H. W., Crosa, J. H. \& Falkow, S. (1977). Construction and characterization of new cloning vehicles. II. A multipurpose cloning system. Gene 2, 95-113.

Bradford, M. M. (1976). A rapid and sensitive method for the quantitation of microgram quantities of protein utilizing the principle of protein-dye binding. Anal Biocbem 72, 248-254.

Davis, B. D. \& Mingioli, E. S. (1950). Mutants of Escherichia coli requiring methionine or vitamin $B_{12} . J$ Bacteriol 60, 17-28.

Demoll, E. \& Shieve, W. (1983). The origin of sulfur in biotin. Biocbem Biopbys Res Commun 110, 243-249.

DeVries, J. K. \& Zubay, G. (1967). DNA-directed peptide synthesis, II. The synthesis of the $\alpha$-fragment of the enzyme $\beta$-galactosidase. Proc Natl Acad Sci USA 57, 267-287.

Eisenberg, M. A. (1987). Biosynthesis of biotin and lipoic acid. In Eschericbia coli and Salmonella typhimurium: Cellular and Molecular Biology, pp. 544-550. Edited by F. C. Neidhardt, J. L. Ingraham, K. Brooks Low, B. Magasanik, M. Schaechter \& H. E. Umbarger. Washington, DC: American Society for Microbiology.

Guha, A. (1971). Divergent orientation of transcription from the biotin locus of Escherichia coli. J Mol Biol 56, 53-62.

Harley, C. B. \& Reynolds, R. P. (1987). Analysis of E. coli promoter sequences. Nucleic Acids Res 15, 2343-2361. 
Hatakeyama, K., Kohama, K., Vertes, A. A., Kobayashi, M., Kurusu, Y. \& Yukawa, H. (1993). Analysis of the biotin biosynthesis pathway in coryneform bacteria : cloning and sequencing of the bio $B$ gene from Brevibacterium flavum. DNA Seq 4, 87-93.

Hayden, M. A., Huang, I., Bussiere, D. E. \& Ashley, G. W. (1992). The biosynthesis of lipoic acid. $J$ Biol Chem 267, 9512-9515.

Higgins, D. G., Bleasby, A. J. \& Fuchs, R. (1992). Clustal v: improved software for multiple sequence alignment. Comput $A p p l$ Biosci 8, 189-191.

Hinnebusch, A. G. \& Fink, G. R. (1983). Repeated DNA sequences upstream from HIS1 also occur at several other co-regulated genes in Saccharomyces cerevisiae. J Biol Chem 258, 5238-5247.

Ifuku, O., Kishimoto, J., Haze, S., Yanagi, M. \& Fukushima, Y. (1992). Conversion of dethiobiotin to biotin in cell-free extracts of Eschericbia coli. Biosci Biotechnol Biocbem 56, 1780-1785.

Ifuku, O., Miyaoka, H., Koga, N., Kishimoto, J., Haze, Wachi, Y. \& Kajiwara, M. (1994). Origin of carbon atoms of biotin ${ }^{13} \mathrm{C}-\mathrm{NMR}$ studies on biotin biosynthesis in Escherichia coli. Eur J Biochem 220, 585-591.

Izumi, Y., Morita, H., Tani, Y. \& Ogata, K. (1974). The pimelyl-CoA synthetase responsible for the first step in biotin biosynthesis by microorganisms. Agric Biol Chem 38, 2257-2262.

Komatsubara, S. (1994). Amino acids: genetically engineered Serratia marcescens. In Recombinant Microbes for Industrial and Agricultural Applications, pp. 467-484. Edited by Y. Murooka \& T. Imanaka. New York: Marcel Dekker.

Laemmli, U. K. (1970). Cleavage of structural proteins during the assembly of the head of bacteriophage T4. Nature 227, 680-685.

Lisser, S. \& Margalit, H. (1993). Complication of E. coli mRNA promoter sequences. Nucleic Acids Res 21, 1507-1516.

Lovenberg, W. (1973). Iron-Sulfur Proteins. Orlando, FL: Academic Press.

Maniatis, T., Fritsh, E. F. \& Sambrook, J. (1982). Molecular Cloning: a Laboratory Manual. Cold Spring Harbor, NY: Cold Spring Harbor Laboratory.

Mark, S. G. (1978). The $\gamma \delta$ sequence of $\mathrm{F}$ is an insertion sequence. J Mol Biol 126, 346-365.

Masuda, M., Takahashi, K., Sakurai, N.,Yanagiya, K., Komatsubara, S. \& Tosa, T. (1995). Further improvement of D-biotin production by a recombinant strain of Serratia marcescens. Process Biochem 30, 553-562.

Matsumoto, H., Tazaki, T. \& Hosogaya, S. (1973). A generalized transducing phage of Serratia marcescens. Jpn J Microbiol 17, 473-479.

Miller, J. H. (1972). Assay of $\beta$-galactosidase. In Experiments in Molecular Genetics, pp. 352-355. Cold Spring Harbor, NY: Cold Spring Harbor Laboratory.

Omori, K., Suzuki, S., Imai, Y. \& Komatsubara, S. (1991). Analysis of the Serratia marcescens proB $A$ operon and feedback control of proline biosynthesis. J Gen Microbiol 137, 509-517.

Osawa, I., Speck, D., Kisou, T., Hayakawa, K., Zinsius, M., Gloeckler, R., Lemoine, Y. \& Kamogawa, K. (1989). Cloning of the biotin synthesis gene from Bacillus sphaericus and expression in $E$. coli and bacilli. Gene 80, 39-40.

Otsuka, A. J., Buoncristiani, M. R., Howard, P. K., Flamm, J., Johnson, C., R, Y., Uchida, K., Cook, C., Ruppert, J. \& Matsuzaki, J. (1988). The Eschericbia coli biotin biosynthetic enzyme sequences predicted from the nucleotide sequence of the bio operon. $J$ Biol Chem 263, 19577-19585.

Parry, R. J. (1983). Biosynthesis of some sulfur containing natural products. Investigations of the mechanism of carbon-sulfur bond formation. Tetrabedron 39, 1212-1238.
Pearson, W. R. \& Lipman, D. J. (1988). Improved tools for biological sequence comparison. Proc Natl Acad Sci USA 85, 2444-2448.

Ploux, O., Soularue, P., Marquet, A., Gloeckler, R. \& Lemoine, Y. (1992). Investigation of first step of biotin biosynthesis in Bacillus sphaericus. Biochem J 287, 685-690.

Prakash, O. \& Eisenberg, M. A. (1979). Biotinyl 5'-adenylate: corepressor role in the regulation of the biotin genes of Escherichia coli K-12. Proc Natl Acad Sci US A 76, 5592-5595.

Ringquist, S., Shinedling, S., Barrick, D., Green, L., Binkley, J., Stormo, G. D. \& Gold, L. (1992). Translation initiation in Escherichia coli: sequences within the ribosome-binding site. Mol Microbiol 6, 1219-1229.

Rosenberg, M. \& Court, D. (1984). Regulatory sequences involved in the promotion and termination of RNA transcription. Annu Rev Genet 13, 319-353.

Sakurai, N. \& Komatsubara, S. (1996). Simple and versatile electrotransformation of Serratia marcescens. Lett Appl Microbiol 23, 23-26.

Sakurai, N., Imai, Y., Masuda, M., Komatsubara, S. \& Tosa, T. (1993a). Construction of a biotin-overproducing strain of Serratia marcescens. Appl Environ Microbiol 59, 2857-2863.

Sakurai, N., Imai, Y., Masuda, M., Komatsubara, S. \& Tosa, T. (1993b). Molecular breeding of a biotin-hyperproducing Serratia marcescens strain. Appl Environ Microbiol 59, 3225-3232.

Sakurai, N., Imai, Y., Masuda, M., Komatsubara, S. \& Tosa, T. (1994). Improvement of a D-biotin-producing recombinant strain of Serratia marcescens. J Biotechnol 36, 63-73.

Sanger, F., Nicklen, S. \& Coulson, A. R. (1977). DNA sequencing with chain-terminating inhibitors. Proc Natl Acad Sci USA 74, 5463-5467.

Sanyal, I., Cohen, G. \& Flint, D. H. (1994a). Biotin synthase: purification, characterization as a $[2 \mathrm{Fe}-2 \mathrm{~S}]$ cluster protein, and in vitro activity of the Eschericbia coli bioB gene product. Biochemistry 33, 3625-3631.

Sanyal, I., Lee, S. \& Flint, D. H. (1994b). Biosynthesis of pimeloylCoA, a biotin precursor in Escherichia coli, follows a modified fatty acid synthesis pathway: ${ }^{13} \mathrm{C}$-labeling studies. $J$ Am Chem Soc 33, $2637-2638$

Shiuan, D. \& Campbell, A. (1988). Transcriptional regulation and gene arrangement of Escherichia coli, Citrobacter freundii and Salmonella typhimurium biotin operons. Gene 67, 203-211.

Stoker, N. G., Fairweather, N. F. \& Spratt, B. G. (1982). Versatile low-copy-number plasmid vectors for cloning in Escherichia coli. Gene 18, 335-341.

Takagi, T. \& Kisumi, M. (1985). Isolation of a versatile Serratia marcescens mutant as a host and molecular cloning of the aspartase gene. J Bacteriol 161, 1-6.

Takeshita, S., Sato, M., Toba, M., Masahashi, W. \& HashimotoGotoh, T. (1987). High-copy-number and low-copy-number plasmid vectors for lac $Z$-complementation and chloramphenicol- or kanamycin-resistance selection. Gene 61, 63-74.

Yanisch-Perron, C., Vieira, J. \& Messing, J. (1985). Improved M13 phage cloning vectors and host strains: nucleotide sequences of M13mp18 and pUC19 vectors. Gene 33, 103-119.

Zhang, S., Sanyal, I., Bulboaca, G. H., Rich, A. \& Flint, D. H. (1994). The gene for biotin synthase from Saccharomyces cerevisiae: cloning, sequencing, and complementation of Escberichia coli strains lacking biotin synthase. Arcb Biochem Biophys 309, 29-35.

Received 30 January 1996; revised 25 June 1996; accepted 17 July 1996. 